\title{
The Influence Of Brand Image And Brand Trust On Satisfaction And Loyalty On Television Products Toshiba Surabaya Region
}

\author{
Bagus Ranu Irwanto and Ani Wulandari \\ Program Studi Manajemen, Fakultas Ekonomi Dan Bisnis \\ Universitas Narotama Surabaya \\ Email Author: ani.wulandari@ narotama.ac.id
}

\begin{abstract}
Given the intense level of competition in the electronics business in Indonesia, the company continues to strive to increase market share and reach new customers and no less importantly the company must work hard in maintaining customer loyalty, including Toshiba products. However, the Top Brand Index value for Toshiba Television products in Indonesia from 2012-2014 has decreased. The decline is not profitable for Toshiba products because this will have an impact on lowering revenue and deteriorating image and customer satisfaction. Based on these problems, this study aims to determine the effect of brand image and brand trust on satisfaction and loyalty in the Surabaya area of Toshiba television products. The population in this study were customers of Toshiba Television products, Surabaya branch, samples were taken were 96 people. This study uses a path analysis model (path analysis). The path analysis technique is one of the statistical analysis techniques used in quantitative research. Based on the test results using the analysis to test the effect of brand image, brand trust, and satisfaction with brand loyalty, the following conclusions can be drawn: Brand Image has a positive and significant effect on Customer Satisfaction, Brand Trust has a positive and significant effect on Customer Satisfaction, Brand Image has a positive and significant effect on customer loyalty, brand trust has a positive and significant effect on customer loyalty, customer satisfaction has a positive and significant effect on customer loyalty, brand image on customer loyalty through customer satisfaction is more dominant than brand trust on customer loyalty through customer satisfaction.
\end{abstract}

\section{Keyword:}

Brand Image, Brand Trust, Satisfaction, Loyalty, Customers

\section{Pendahuluan}

\subsection{Latar Belakang}

Perkembangan teknologi yang semakin maju juga memicu tumbuhnya industri baru, pasar baru, dan pesaing baru. Ketatnya persaingan usaha di bidang sejenis ini membuat pihak produsen semakin terpacu dan berlombalomba untuk menghasilkan produk yang dibutuhkan dan diinginkan konsumen, baik dari segi kualitas, jumlah, maupun karakteristik produk. Namun strategi pemasaran yang baik akan berhasil apabila para pengusaha benarbenar mengenal karakter dan mengerti apa yang diinginkan oleh konsumennya.

Mengingat tingkat persaingan bisnis elektronik di Indonesia yang ketat menjadikan perusahaan senantiasa berusaha untuk dapat meningkatkan pangsa pasar dan meraih konsumen baru dan yang tidak kalah penting perusahaan harus bekerja keras dalam mempertahankan loyalitas konsumennya, tak terkecuali produk Toshiba. Sehingga konsumen bisa loyal terhadap produk. Tanpa citra merek dan kepuasan yang kuat dan positif, sangatlah sulit bagi perusahaan untuk menarik pelanggan baru dan mempertahankan yang sudah ada.

Loyalitas konsumen terhadap suatu merek/produk, sangat tergantung pada kemampuan perusahaan dalam memberikan citra merek. Citra merek (brand image) merupakan representasi dari keseluruhan persepsi terhadap merek dan dibentuk dari informasi dan pengalaman masa lalu terhadap merek itu. Citra terhadap merek berhubungan dengan sikap yang berupa keyakinan dan preferensi terhadap suatu merek. Citra yang baik dari suatu merek dapat mengarahkan pada loyalitas konsumen terhadap suatu merek. Penting bagi perusahaan untuk membangun citra yang positif dari merek yang dihasilkannya, agar citra merek yang dibangun dapat dipersepsikan dengan baik oleh konsumen. Melalui loyalitas konsumen, suatu merek dapat bertahan di dalam benak konsumen sehingga dapat setia terhadap merek yang akan di konsumsi. Brand image yang kuat akan mempengaruhi konsumen untuk setia terhadap produk yang akan mereka konsumsi. Citra merek selain memberikan kontribusi terhadap loyalitas pelanggan, citra merek juga mampu memberikan pengaruh terhadap kepuasan pelanggan. Menurut Kotler 
(2009) kepuasan (satisfaction) adalah perasaan senang atau kecewa seseorang yang timbul karena membandingkan kinerja yang dipersepsikan produk atau hasil terhadap ekspektasi mereka. Jika kinerja gagal memenuhi ekspektasi maka pelanggan akan tidak puas, sebaliknya jika kinerja melebihi ekspektasi, pelanggan akan sangat puas atau senang.

Demikian juga pada perusahaan-perusahaan yang ingin memberikan pelayanan terhadap pelanggan dengan efektif dan efisien. Begitu juga dengan Toshiba. Toshiba adalah perusahaan Jepang yang memproduksi dan memasarkan berbagai peralatan listrik dan produk elektronik yang canggih, yang berkantor pusat di Tokyo, Jepang. Toshiba dinilai sebagai perusahaan no 7 dunia untuk produsen terintegrasi untuk peralatan listrik, elektronik.

Toshiba Corporation adalah salah satu perusahaan diversifikasi produsen dan pemasar produk digital, perangkat elektronik dan komponen, sistem infrastruktur sosial dan Home appliances. Sebagai pendiri dan inovator terkemuka dalam komputasi portabel dan produk-produk jaringan, Perusahaan ini bermarkas di Tokyo, Jepang. Selain itu perusahaan ini merupakan perusahaan elektronik terbesar di dunia . Toshiba saat ini kebanyakan buatan RRC. Toshiba mulai mengeluarkan hasil produksinya yaitu notebook, PC. Dan mulai melakukan perluasan dengan memproduksi berbagai macam barang elektronik lainnya, seperti Televisi, Lemari Es, Air Conditioner dan Mesin Cuci.

Produk-produk Televisi menjadi obyek penelitian, karena kondisi bisnis pada produk ini sudah terjadi persaingan yang sangat ketat, dengan pasar yang juga sudah sangat sesak. Penelitian ini lebih memfokuskan pada Televisi LED, kayar LED terbaru dapat menghasilkan kualitas gambar yang jauh lebih baik daripada layar plasma. Jika kita memilih LED maka kita akan memperoleh kualitas gambar televisi yang cukup bagus.Kesesakan tersebut dapat diketahui dengan memperhatikan merk-merk yang sudah ada seperti LG,Sharp,Samsung dan seterusnya, dengan spesifikasi produk hampir mencapai ratusan jenis.

Top Brand Index diukur dengan menggunakan 3 parameter, yaitu top of mind awareness (yaitu berdasarkan atas merek yang pertama kali disebut oleh responden ketika kategori produknya disebutkan), last used (yaitu didasarkan atas merek yang terakhir kali digunakan/ konsumsi di masa mendatang). Nilai masing- masing parameter untuk sebuah merek di dalam kategori produk tertentu diperoleh dengan cara menghitung presentase frekuensi keseluruhan merek. Tob Brand Index selanjutnya diperoleh dengan cara menghitung rata- rata terbobot masingmasing parameter

Berdasarkan nilai Top Brand Index pada produk Televisi Toshiba di Indonesia dari tahun 2012-2014 mengalami penurunan, pada tahun 2012 nilai Top Brand Index sebesar 7,6\%, tahun 2013 nilai Top Brand Index sebesar 7,4\% dan mengalami penurunan pada tahun 2014 sebesar 7,2\%. Penurunan tersebut tidak menguntungkan bagi produk Toshiba karena hal ini akan berdampak pada penurunan pendapatan dan penurunan citra serta kepuasan konsumen. Padahal produk Televisi Toshiba mempunyai keunggulan di citranya sebagai produk elektronik legendaries dan mempunyai teknologi autoview dan autoclean. Melalui loyalitas konsumen, suatu merek dapat bertahan di dalam benak konsumen sehingga dapat setia terhadap merek yang akan di konsumsi.

Pemahaman yang lengkap tentang Loyalitas Merek tidak dapat diperoleh tanpa penjelasan mengenai kepercayaan merek dan bagaimana hubungannya dengan Loyalitas Merek. Dalam pemasaran industri, para peneliti telah menemukan bahwa kepercayaan terhadap sales dan supplier merupakan sumber dari loyalitas.

Menurut Lau dan Lee dalam Rizan (2012 : 3) terdapat tiga faktor yang mempengaruhi kepercayaan merek. Ketiga factor ini berhubungan dengan tiga entitas yang tercakup dalam hubungan antara merek dan konsumen. Adapun ketiga faktor tersebut adalah merek itu sendiri, perusahaan pembuat merek, dan konsumen. Delgado dalam Ferrinnadewi (2008) kepercayaan merek merupakan kemampuan merek untuk dipercaya (brand reliability), yang bersumber pada keyakinan konsumen bahwa produk tersebut mampu memenuhi nilai yang dijanjikan dan intensi baik merek (brand intention) yang didasarkan pada keyakinan konsumen bahwa merek tersebut mampu mengutamakan kepentingan konsumen. Kepercayaan konsumen terhadap merek (brand trust) akan berdampak terhadap kesetiaan sikap ataupun perilaku konsumen terhadap suatu merek.

Berdasarkan latar belakang tersebut, maka peneliti bermaksud untuk melakukan penelitian tentang pengaruh citra merek dan kepercayaan merek terhadap kepuasan dan loyalitas konsumen yang terwujud dalam keinginan untuk membeli dan merekomendasikan produk tersebut, maka peneliti tertarik untuk mengadakan penelitian dengan

judul : "Pengaruh Citra Merek dan Kepercayaan Merek Terhadap Kepuasan dan Loyalitas Pada Produk Televisi Toshiba Wilayah Surabaya"

\subsection{Perumusan Masalah}

Perumusan masalah yang diajukan dalam penelitian ini adalah :

1. Apakah terdapat pengaruh Citra Merek Terhadap Kepuasan Pelanggan ?

2. Apakah terdapat pengaruh Kepercayaan Merek Terhadap Kepuasan Pelanggan ?

3. Apakah terdapat pengaruh Citra Merek Pelanggan Terhadap Loyalitas Pelanggan ? 
4. Apakah terdapat pengaruh Kepercayaan Merek Terhadap Loyalitas Pelanggan?

5. Apakah terdapat pengaruh Kepuasan Pelanggan Terhadap Loyalitas Pelanggan ?

\section{TINJAUAN PUSTAKA}

\subsection{Kepercayaan terhadap Merek}

Pemahaman yang lengkap tentang loyalitas merek tidak tidak dapat diperoleh tanpa penjelasan mengenai kepercayaan terhadap merek (trust in brand) dan bagaimana hubungannya dengan loyalitas merek. Dalam pemasaran industri para peneliti telah menemukan bahwa kepercayaan terhadap sales dan suplier merupakan sumber dari loyalitas. (Riana 2008:187)

Kepercayaan merek adalah persepsi akan kehandalan dari sudut pandang konsumen didasarkan pada pengalaman, atau lebih pada urutan-urutan transaksi atau interaksi yang dicirikan oleh terpenuhinya harapan akan kinerja produk dan kepuasan (Riset Costabile dalam Ferinnadewi, 2008). Kepercayaan terbangun karena adanya harapan bahwa pihak lain akan bertindak sesuai dengan kebutuhan dan keinginan konsumen.

\subsection{Citra Merek}

Citra merek merupakan petunjuk yang akan digunakan oleh konsumen untuk mengevaluasi produk ketika konsumen tidak memiliki pengetahuan yang cukup tentang suatu produk. Terdapat kecnderungan bahwa konsumen akan memilih produk yang telah dikenal baik melalui pengalaman menggunakan produk maupun berdasarkan informasi yang diperoleh melalui berbagai sumber.

Dari definisi-definisi citra merek di atas, dapat disimpulkan bahwa citra merek merupakan kumpulan kesan yang ada di benak konsumen mengenai suatu merek yang dirangkai dari ingatan-ingatan konsumen terhadap merek tersebut. Sda tiga bagian yang terdapat dalam pengukuran citra merek. Bagian pertama adalah atribut. Atribut adalah ciri-ciri atau berbagai aspek dari merek yang diiklankan. Atribut juga dibagi menjadi dua bagian yaitu hal- hal yang tidak berhubungan dengan produk (contoh: harga, kemasan, pemakai, dan citra penggunaan), dan hal-hal yang berhubungan dengan produk (contoh: warna, ukuran, desain). Kemudian bagian kedua pengukuran citra merek menurut Shimp adalah manfaat. Manfaat dibagi menjadi tiga bagian yaitu fungsional, simbolis, dan pengalaman.

\subsection{Kepuasan}

Menurut Kotler dalam Herizon, dkk,( 2011), kepuasan adalah sejauh mana kinerja yand diberikan oleh sebuah produk sepadan dengan harapan pembeli. Shermerhorn berpendapat bahwa pada dasarnya tujuan dari suatu organisasi bisnis adalah memproduksi barang atau jasa yang memuaskan kebutuhan Konsumennya. Dengan kata lain perusahaan berusaha untuk menciptakan Konsumen yang merasa puas, manajemen perusahaan harus mengetahui hal - hal yang menyebabkan terciptanya kepuasan Konsumen.

Kepuasan yang dirasakan oleh pelanggan mempunyai konsekuensi perilaku berupa komplain dan loyalitas pelanggan, sehingga apabila organisasi atau perusahaan dapat memperhatikan segala hal yang dapat membentuk kepuasan pelanggan, maka kepuasan yang dirasakan oleh pelanggan secara keseluruhan akan terbentuk.

Naser et al dalam Wijayanti (2010:4) mengatakan bahwa kepuasan pelanggan sangat tergantung pada bagaimana tingkat kualitas produk yang ditawarkan, namun sayangnya Naser et al mencatat kurangnya perhatian pada hubungan antara kualitas produk dengan kepuasan pelanggan dalam konteks perusahaan jasa. Penelitian Naser menunjukkan bahwa atribut-atribut produk mempengaruhi kepuasan nasabah. Sedangkan penelitian Selnes menunjukkan bahwa kinerja produk sebagaimana dipersepsikan pelanggan mempengaruhi kepuasan pelanggan. Sementara hasil penelitian Andreassen dan Lindestad membuktikan bahwa kualitas produk diukur dari persepsi pelanggan atas tingkat kerusakan suatu produk mempengaruhi tingkat kepuasan (Wijayanti, 2010:4)

\subsection{Loyalitas Pelanggan}

Loyalitas Pelanggan merupakan suatu konsep yang sangat penting dalam strategi pemasaran. Keberadaan Pelanggan yang loyal pada merek sangat diperlukan agar perusahaan dapat bertahan hidup. Loyalitas dapat diartikan sebagai suatu komitmen yang mendalam untuk melakukan pembelian ulang produk atau jasa yang menjadi preferensinya secara konsisten pada masa yang akan datang dengan cara membeli ulang merek yang sama meskipun ada pengaruh situasional dan usaha pemasaran yang dapat menimbulkan perilaku peralihan.

Menurut Oliver dalam Kotler dan Keller (2007 : 175) mendefinisikan kesetiaan sebagai “ komitmen yang dipegang kuat untuk membeli lagi atau berlangganan lagi produk atau jasa tertentu dimasa depan meskipun ada pengaruh situasi dan usaha pemasaran yang berpotensi menyebabkan peralihan perilaku". Loyalitas dapat didefinisikan sebagai sikap konsumen terhadap suatu produk / merek yang diwujudkan dengan membeli terus 
menerus produk yang sama sepanjang waktu yang merupakan hasil dari pembelajaran dimana produk dapat memuaskan kebutuhannya

Aaker (2008 : 8) mendefinisikan Loyalitas Pelanggan sebagai "A measure of the attachment that a costumer has a brand". Loyalitas merek menunjukkan adanya suatu ikatan antara pelanggan dengan merek tertentu dan ini sering kali ditandai dengan adanya pembelian ulang dari pelanggan.

\subsection{Pengaruh Kepercayaan Merek terhadap Kepuasan Pelanggan dan Loyalitas Pelanggan}

Delgado dalam Ferrinnadewi (2008) kepercayaan merek merupakan kemampuan merek untuk dipercaya (brand reliability), yang bersumber pada keyakinan konsumen bahwa produk tersebut mampu memenuhi nilai yang dijanjikan dan intensi baik merek (brand intention) yang didasarkan pada keyakinan konsumen bahwa merek tersebut mampu mengutamakan kepentingan konsumen. Kepercayaan konsumen terhadap merek (brand trust) akan berdampak terhadap kesetiaan sikap ataupun perilaku konsumen terhadap suatu merek.

Kepuasan Pelanggan merupakan strategi jangka panjang yang membutuhkan komitmen, baik menyangkut sumber dana maupun sumberdaya manusia. Hal ini dirasakan sangat urgen, sebab para pelanggan akan merekomendasikan kepada pelanggan potensial merupakan fungsi kepuasan atas pengalamannya. Kepuasan pelanggan akan mempengaruhi perilaku membeli, dimana pelanggan yang puas cenderung loyal. (Sugiharto, 2007 : 54)

\subsection{Pengaruh Citra Merek terhadap Kepuasan Pelanggan dan Loyalitas Pelanggan}

Brand Image atau citra merek merupakan persepsi konsumen tentang suatu merek sebagai refleksi dari asosiasi merek yang ada pada pikiran konsumen (Keller 2008). Menurut Schiffman dan Kanuk (2009), loyalitas merek adalah preferensi konsumen secara konsisten untuk melakukan pembelian pada merek yang sama pada produk yang spesifik atau kategori pelayanan tertentu. Hubungan antara citra merek dengan loyalitas merek terletak pada keinginan-keinginan dan pilihan konsumen (preference) atas suatu merek adalah merupakan sikap konsumen. Konsumen akan menunjukkan loyalitas merek ketika ia tidak hanya melakukan pembelian berulang tapi ia juga benar-benar menyukai dan memilih merek tersebut

Disisi lain bahwa citra yang baik dari sebuah produk dapat membantu konsumen untuk mengambil keputusan pembelian. Atau dengan kata lain, citra yang positif dari sebuah produk pada dasarnya membantu penyederhanaan keputusan konsumen dalam membeli sebuah produk. Dengan bantuan citra positif inilah konsumen dapat mengambil keputusan membeli dan merekomendasikan produk tersebut kepada orang lain.

\subsection{Hipotesis}

Berdasarkan pada teori yang telah dikemukakan sebelumnya, maka hipotesis penelitian yang diajukan adalah:

1. Citra Merek berpengaruh positif dan signifikan terhadap Kepuasan Pelanggan

2. Kepercayaan Merek berpengaruh positif dan signifikan terhadap Kepuasan Pelanggan

3. Citra Merek berpengaruh positif dan signifikan terhadap Loyalitas Pelanggan

4. Kepercayaan Merek berpengaruh positif dan signifikan terhadap Loyalitas Pelanggan

5. Kepuasan Pelanggan berpengaruh positif dan signifikan terhadap Loyalitas Pelanggan

\section{Metode Penelitian}

Penelitian ini menggunakan pendekatan kuantitatif yaitu penelitin yang menitik beratkan pada pengujian hipotesis. Data yang digunakan harus terukur dan akan mengasilkan suatu simpulan yang dapat digeneralisasikan.

Jenis penelitian ini adalah explanatory research (penelitian penjelasan). Penelitian penjelasan merupakan penelitian yang menyoroti hubungan variabel-variabel penelitian dan menguji hipotesa yang telah dirumuskan sebelumnya. Oleh karena itu, penelitian ini juga dinamakan pengujian hipotesa atau testing research.

Adapun dasar utama pemilihan ini adalah untuk menguji hipotesa yang telah digunakan sebelumnya . melalui uji hipotesis tersebut diharapkan dapat menjelaskan pengaruh Citra Merek dan Kepercayaan Merek Terhadap Kepuasan dan Loyalitas.

\subsection{Populasi dan Sampel Penelitian Populasi}

Populasi merupakan kelompok subyek / obyek yang memiliki ciri-ciri atau karakteristik-karakteristik tertentu yang berbeda dengan kelompok subyek / obyek yang lain, dan kelompok tersebut akan dikenai generalisasi dari hasil penelitian (Sugiyono, 2011). Populasi dalam penelitian ini adalah pelanggan produk Televisi Toshiba Cabang Surabaya. 


\subsection{Sampel}

Sampel adalah bagian dari jumlah dan karateristik yang dimiliki oleh populasi tersebut. Bila populasi besar, dan penelitian tidak mungkin mempelajari semua yang ada pada populasi, misalnya keterbatasan dana, tenaga dan waktu maka penelitian dapat menggunakan sampel yang diambil dari populasi itu, (Sugiyono, 2011). Populasi dalam penelitian ini tidak diketahui jumlahnya. Menurut Wibisono dalam Riduwan dan Akdon (2013), rumus dalam menghitung sampel pada populasi yang tidak diketahui adalah sebagai berikut:

$$
n=\left(\frac{Z_{\alpha / 2} \sigma}{e}\right)^{2}=\left(\frac{(1,96) \cdot(0,25)}{0,05}\right)^{2}=96,04
$$

Keterangan :

Gambar 1. Rumus menghitung sampel pada populasi

$$
\begin{aligned}
& \mathrm{N}=\text { Ukuran Sampel } \\
& \begin{array}{l}
Z_{\alpha / 2} \sigma^{\prime}=\text { Nilai standart sebesar } 1,96 \\
\mathrm{E} \quad=\text { Tingkat kesalahan } 20 \%
\end{array}
\end{aligned}
$$

Dengan begitu peneliti yakin dengan tingkat kepercayaan 95\% bahwa sampel random berukuran 96,04. Jadi, sampel yang diambil sebesar 96 orang.

\subsection{Teknik Analisis Data}

Penelitian ini menggunakan model analisis path (analisis jalur). Teknik analisis jalur (path analysis) adalah salah satu teknik analisis statistik yang digunakan di dalam penelitian kuantitatif. Analisis jalur (path analysis) biasanya menggunakan istilah pengaruh langsung dan pengaruh tidak langsung, dikarenakan ada variabel perantara / interverning / variabel mediasi. path analysis digunakan untuk menganalisis pola hubungan antar variabel dengan tujuan untuk mengetahui pengaruh langsung dan tidak langsung seperangkat variabel bebas (exogen) terhadap variabel terikat (endogen).

Berdasarkan untuk mengetahui pola hubungan masing -masing variabel tersebut maka dapat disusun sistem persamaan strukturnya sebagai berikut :

1. Pengaruh Citra Merek dan Kepercayaan Merek terhadap Kepuasan Pelanggan perusahaan dengan persamaan sebagai berikut :

$\mathrm{KP}=\mathrm{b} 1 \mathrm{CM}+\mathrm{b} 2 \mathrm{KM}+\mathrm{e} 1$

2. Pengaruh Citra Merek, Kepercayaan Merek dan Kepuasan Pelanggan terhadap Loyalitas Pelanggan dengan persamaan sebagai berikut :

$$
\mathrm{LP}=\mathrm{b} 3 \mathrm{CM}+\mathrm{b} 4 \mathrm{KM}+\mathrm{b} 5 \mathrm{KP}+\mathrm{e} 2
$$

\section{Hasil Penelitian Dan Pembahasan}

\subsection{Hasil Pengujian Path Analisis}

Dalam langkah path analysis yang pertama adalah menguji sub-struktur 1. Berdasarkan hasil dari PASW statistics 20.0, dapat dilihat sebagai berikut:

1. Menguji Sub-Struktur 1, pengaruh Citra Merek dan Kepercayaan Merek terhadap Kepuasan Pelanggan Model 1: Summary X1 dan X2 terhadap X3

Koefisien determinasi atau R-square menunjukkan presentase seberapa besar pengaruh variabel bebas terhadap perubahan variabel terikat. Berikut ini determinasi $\left(\mathrm{R}^{2}\right)$ yang dihasilkan : 
Tabel 1. Summary Sub-Struktur 1

\begin{tabular}{cccc}
\hline \multirow{2}{*}{ Model } & $\mathrm{R}$ & \multicolumn{2}{c}{ Model Summary } \\
R Square & Adjusted R Square & $\begin{array}{c}\text { Std. Error of the } \\
\text { Estimate }\end{array}$ \\
\hline 1 & $\begin{array}{c}.717^{\mathrm{a}} \\
\text { a. Predictors: (Constant), Kepercayaan Merek, Citra Merek }\end{array}$ & $\begin{array}{c}.514 \\
\end{array}$
\end{tabular}

Berdasarkan tabel diatas dapat dijelaskan Citra Merek dan Kepercayaan Merek mampu menjelaskan perubahan variabel Kepuasan Pelanggan sebesar 51.4\% [lihat R Square 0,514] sedang sisanya 48.6\% [100\% 51.4\%] dijelasksan oleh variabel lain selain Citra Merek dan Kepercayaan Merek.

Uji F digunakan untuk menguji cocok atau tidaknya model regresi yang dihasilkan dan uji t digunakan untuk menguji pengaruh masing-masing variabel bebas terhadap variabel terikat. Adapun hasil dari uji $\mathrm{F}$ dan uji $\mathrm{t}$ adalah sebagai berikut :

Tabel 2 : Hasil Uji F

\begin{tabular}{ccccccc}
\hline & & \multicolumn{3}{c}{ ANOVA $^{\mathrm{a}}$} \\
& Model & Sum of Squares & df & Mean Square & F & Sig. \\
\hline 1 & Regression & 215.561 & 2 & 107.781 & 49.120 & $.000^{\mathrm{b}}$ \\
& Residual & 204.064 & 93 & 2.194 & & \\
& Total & 419.625 & 95 & & & \\
\hline
\end{tabular}

a. Dependent Variable: Kepuasan Pelanggan

b. Predictors: (Constant), Kepercayaan Merek, Citra Merek

Berdasarkan uji $\mathrm{F}$ pada tabel 4.10 di atas menunjukkan tingkat signifikan untuk uji $\mathrm{F}$ sebesar 0,000. Karena nilai probabilitas $<0,05$ (sig < 5\%), berarti Citra Merek $\left(\mathrm{X}_{1}\right)$, Kepercayaan Merek $\left(\mathrm{X}_{2}\right)$, berpengaruh terhadap Kepuasan Pelanggan $\left(\mathrm{X}_{3}\right)$, sehingga model regresi yang dihasilkan adalah cocok atau sesuai dalam menerangkan Loyalitas Pelanggan.

Tabel 3 : Hasil Uji t

\begin{tabular}{|c|c|c|c|c|c|c|}
\hline \multirow{4}{*}{\multicolumn{2}{|c|}{ Model }} & \multicolumn{3}{|c|}{ Coefficients $^{\mathrm{a}}$} & \multirow{4}{*}{$\mathrm{t}$} & \multirow{4}{*}{ Sig. } \\
\hline & & \multirow{2}{*}{\multicolumn{2}{|c|}{$\begin{array}{l}\text { Unstandardized } \\
\text { Coefficients }\end{array}$}} & \multirow{3}{*}{$\begin{array}{c}\text { Standardized } \\
\text { Coefficients } \\
\text { Beta }\end{array}$} & & \\
\hline & & & & & & \\
\hline & & $\mathrm{B}$ & Std. Error & & & \\
\hline \multirow[t]{3}{*}{1} & (Constant) & 5.240 & 1.249 & & 4.195 & .000 \\
\hline & Citra Merek & .642 & .090 & .562 & 7.121 & .000 \\
\hline & Kepercayaan Merek & .332 & .096 & .274 & 3.473 & .001 \\
\hline
\end{tabular}

Hasil uji t pada tabel di atas menunjukkan bahwa :

1) Variabel Citra Merek (X1) tingkat signifikan sebesar 0.000. Karena tingkat signifikan pada variabel ini lebih kecil dari 5\% (sig < 5\%). Hal ini berarti variabel Citra Merek (X1) berpengaruh terhadap Kepuasan Pelanggan.

2) Variabel Kepercayaan Merek (X2) tingkat signifikan sebesar 0,001. Karena tingkat signifikan pada variabel ini lebih kecil dari 5\% (sig < 5\%). Hal ini berarti variabel Kepercayaan Merek (X2) berpengaruh terhadap Kepuasan Pelanggan.

Berdasarkan hasil uji analisis jalur sub-struktur 1 (X1; X2; dan X3) masing-masing diperoleh nilai:

a. $\quad$ y $1 \times 1=$ Beta $=0,562[\mathrm{t}=7.121$ dan probabilitas $(\mathrm{sig})=0,000]$

b. $\rho y 1 \times 2=$ Beta $=0,274[\mathrm{t}=3.473$ dan probabilitas $($ sig $)=0,001]$

c. Besarnya koefisien residu $\rho y 1 \varepsilon 1=1-\mathrm{R}^{2}=1-0,514=0,486$

Dengan demikian didapat diagram jalur sub struktur 1, yaitu sebagai berikut : 


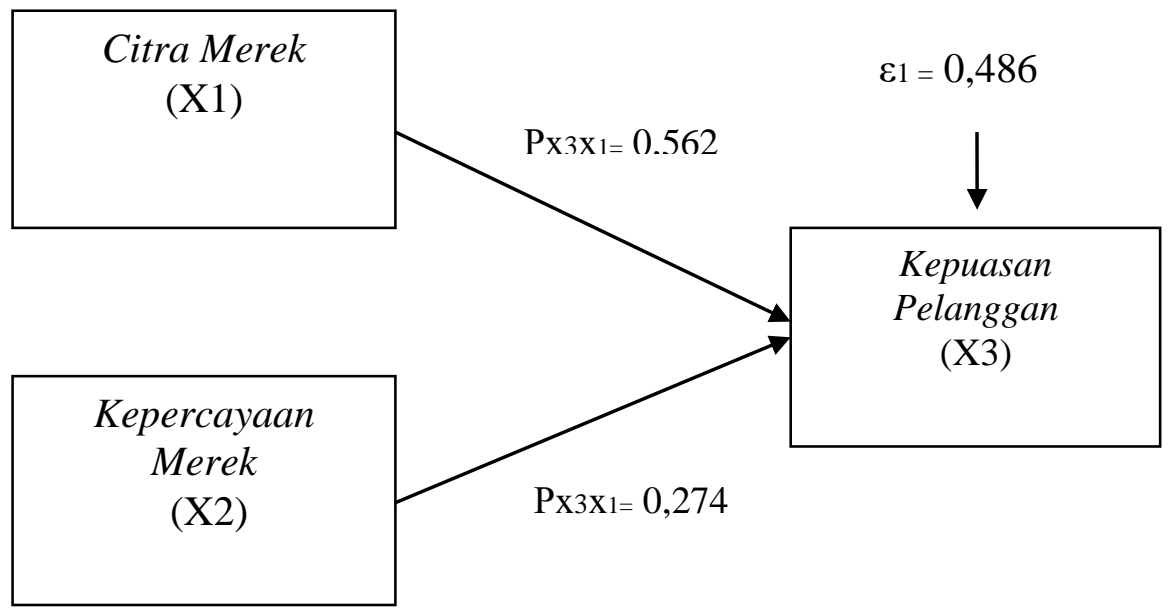

Gambar 2. Sub-Struktur 1: X1 dan X2 terhadap X3

2. Menguji Sub-Struktur 2, pengaruh Citra Merek, Kepercayaan Merek dan Kepuasan Pelanggan Terhadap Loyalitas Pelanggan

Model 1: Summary X1, X2 dan X3 terhadap Y

Koefisien determinasi atau R-square menunjukkan presentase seberapa besar pengaruh variabel bebas terhadap perubahan variabel terikat. Berikut ini determinasi $\left(\mathrm{R}^{2}\right)$ yang dihasilkan :

Tabel 4. Summary Sub-Struktur 2

\begin{tabular}{|c|c|c|c|c|}
\hline \multicolumn{5}{|c|}{ Model Summary } \\
\hline Model & $\mathrm{R}$ & R Square & Adjusted R Square & $\begin{array}{l}\text { Std. Error of the } \\
\text { Estimate }\end{array}$ \\
\hline 1 & $.598^{\mathrm{a}}$ & .357 & .336 & 1.61775 \\
\hline
\end{tabular}

Berdasarkan tabel diatas dapat dijelaskan Citra Merek dan Kepercayaan Merek dan Kepuasan Pelanggan mampu menjelaskan perubahan variabel Loyalitas Pelanggan sebesar 35.7\% [lihat R Square 0,357] sedang sisanya $64.7 \%$ [100\% - 35.7\%] dijelasksan oleh variabel lain selain Citra Merek dan Kepercayaan Merek dan Kepuasan Pelanggan.

Uji F digunakan untuk menguji cocok atau tidaknya model regresi yang dihasilkan dan uji t digunakan untuk menguji pengaruh masing-masing variabel bebas terhadap variabel terikat. Adapun hasil dari uji F dan uji t adalah sebagai berikut :

Tabel 5. Hasil Uji F

\begin{tabular}{|c|c|c|c|c|c|c|}
\hline \multicolumn{7}{|c|}{$\mathrm{ANOVA}^{\mathrm{a}}$} \\
\hline & odel & Sum of Squares & $\mathrm{df}$ & Mean Square & $\mathrm{F}$ & Sig. \\
\hline \multirow[t]{3}{*}{1} & Regression & 133.883 & 3 & 44.628 & 17.052 & $.000^{\mathrm{b}}$ \\
\hline & Residual & 240.774 & 92 & 2.617 & & \\
\hline & Total & 374.656 & 95 & & & \\
\hline
\end{tabular}

Berdasarkan uji $\mathrm{F}$ pada tabel 5 di atas menunjukkan tingkat signifikan untuk uji $\mathrm{F}$ sebesar 0,000 . Karena nilai probabilitas $<0,05(\mathrm{sig}<5 \%)$, berarti Citra Merek $\left(\mathrm{X}_{1}\right)$, Kepercayaan Merek $\left(\mathrm{X}_{2}\right)$, Kepuasan Pelanggan $\left(\mathrm{X}_{3}\right)$ berpengaruh terhadap Loyalitas Pelanggan $(\mathrm{Y})$, sehingga model regresi yang dihasilkan adalah cocok atau sesuai dalam menerangkan Loyalitas Pelanggan. 
Tabel 6 : Hasil Uji t

\begin{tabular}{|c|c|c|c|c|c|c|}
\hline \multirow{4}{*}{\multicolumn{2}{|c|}{ Model }} & \multicolumn{3}{|c|}{ Coefficients $^{\mathrm{a}}$} & \multirow{4}{*}{$\mathrm{t}$} & \multirow{4}{*}{ Sig. } \\
\hline & & \multirow{2}{*}{\multicolumn{2}{|c|}{$\begin{array}{l}\text { Unstandardized } \\
\text { Coefficients }\end{array}$}} & Standardized & & \\
\hline & & & & Coefficients & & \\
\hline & & $\mathrm{B}$ & Std. Error & Beta & & \\
\hline \multirow[t]{4}{*}{1} & (Constant) & 8.637 & 1.488 & & 5.806 & .000 \\
\hline & Citra Merek & .245 & .122 & .226 & 1.998 & .049 \\
\hline & Kepercayaan Merek & .230 & .111 & .200 & 2.068 & .041 \\
\hline & Kepuasan Pelanggan & .473 & .113 & .500 & 4.173 & .000 \\
\hline
\end{tabular}

a. Dependent Variable: Loyalitas Pelanggan

Hasil uji t pada tabel di atas menunjukkan bahwa :

1. Variabel Citra Merek $\left(\mathrm{X}_{1}\right)$ tingkat signifikan sebesar 0.049. Karena tingkat signifikan pada variabel ini lebih kecil dari 5\% (sig < 5\%). Hal ini berarti variabel Citra Merek $\left(\mathrm{X}_{1}\right)$ secara parsial berpengaruh terhadap Loyalitas Pelanggan.

2. Variabel Kepercayaan Merek $\left(\mathrm{X}_{2}\right)$ tingkat signifikan sebesar 0,041 . Karena tingkat signifikan pada variabel ini lebih kecil dari 5\% (sig < 5\%). Hal ini berarti variabel Kepercayaan Merek $\left(\mathrm{X}_{2}\right)$ berpengaruh terhadap Loyalitas Pelanggan.

3. Variabel Kepuasan Pelanggan $\left(\mathrm{X}_{3}\right)$ tingkat signifikan sebesar 0,000. Karena tingkat signifikan pada variabel ini lebih kecil dari 5\% (sig < 5\%). Hal ini berarti variabel Kepuasan Pelanggan $\left(\mathrm{X}_{3}\right)$ berpengaruh terhadap Loyalitas Pelanggan.

Berdasarkan hasil uji analisis jalur sub-struktur 2(X1; X2; X3 Terhadap Y) masing-masing diperoleh nilai:

a. $\quad$ pyx $1=\operatorname{Beta}=0,226[\mathrm{t}=1.998$ dan probabilitas $(\mathrm{sig})=0,049]$

b. $\rho \mathrm{yx} 2=\mathrm{Beta}=0,200[\mathrm{t}=2.068$ dan probabilitas $(\mathrm{sig})=0,041]$

c. $\rho \mathrm{yx} 3=\mathrm{Beta}=0,500[\mathrm{t}=4.173$ dan probabilitas $(\mathrm{sig})=0,000]$

d. Besarnya koefisien residu $\rho y 1 \varepsilon 2=1-\mathrm{R}^{2}=1-0,357=0,643$

Dengan demikian didapat tabel dan diagram jalur sub struktur 2, yaitu sebagai berikut :

Tabel 7. Pengaruh Antar Variabel Penelitian

\begin{tabular}{|c|c|c|c|c|c|}
\hline Sub-struktı & $\begin{array}{c}\text { Koefisien } \\
\text { Jalur }\end{array}$ & Langsung & $\begin{array}{c}\text { Pengaruh } \\
\text { Tidak } \\
\text { Langsung } \\
\text { melalui X3 } \\
\text { hadap Kepu }\end{array}$ & Total & $\begin{array}{c}\text { Pengaruh } \\
\text { Bersama } \\
\left(\mathrm{R}^{2}\right)\end{array}$ \\
\hline $\mathrm{X} 1$ (Citra $\rightarrow$ Kepuasan) & 0,562 & $0,316 \%$ & - & $0,316 \%$ & 0,514 \\
\hline $\mathrm{X} 2$ (Kepercayaan $\rightarrow$ Kepuasan) & 0,274 & $0,75 \%$ & - & $0.75 \%$ & $(51.4 \%)$ \\
\hline$\varepsilon 1$ & 0,486 & - & - & - & \\
\hline \multicolumn{6}{|c|}{ Sub-struktur 2 (Citra Merek, Kepercayaan dan Kepuasan TerhadapLoyalitas) } \\
\hline X1 (Citra $\rightarrow$ Loyalitas) & 0,226 & $5,10 \%$ & $33.2 \%$ & $38.30 \%$ & 0,357 \\
\hline $\mathrm{X} 2$ (Kepercayaan $\rightarrow$ Loyalitas) & 0,200 & $4 \%$ & $17.7 \%$ & $21.7 \%$ & $(35.7 \%)$ \\
\hline X3 (Kepuasan $\rightarrow$ Loyalitas) & 0,500 & $25 \%$ & - & - & \\
\hline$\varepsilon 2$ & 0,643 & - & - & - & \\
\hline
\end{tabular}




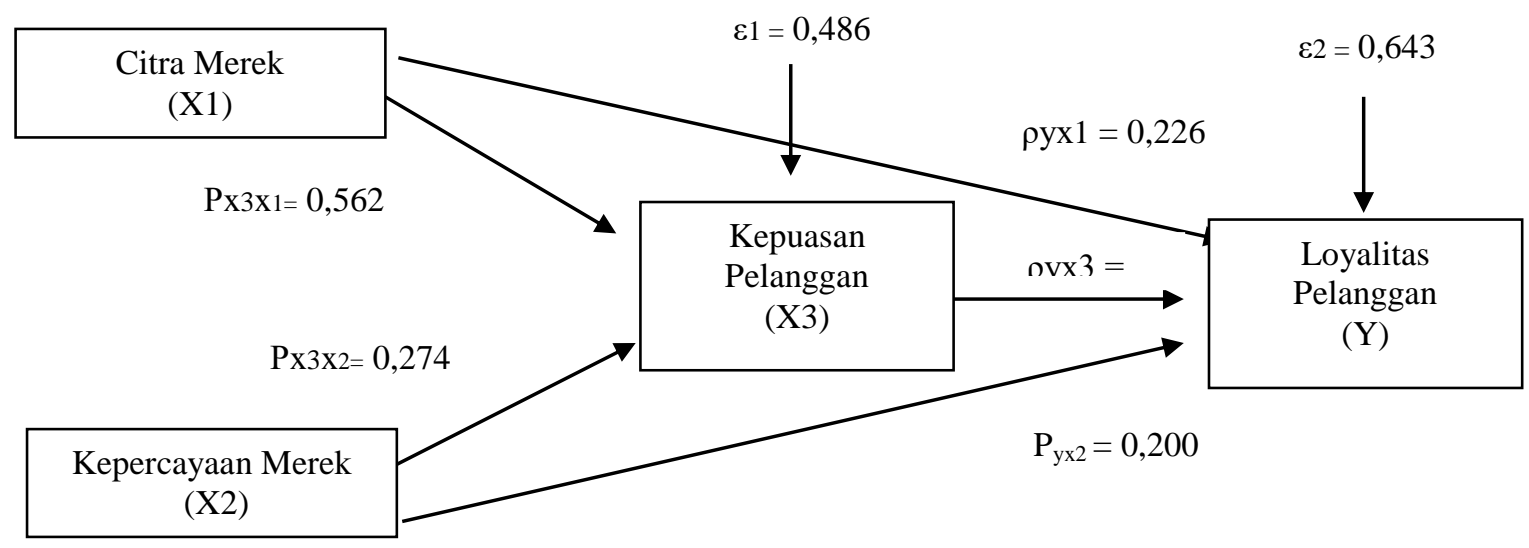

Gambar 3. Sub-Struktur 2 : X1, X2 dan X3 terhadap Y

1. Pengaruh tidak langsung, Citra Merek $(\mathrm{X} 1)$ ke Loyalitas Pelanggan $(\mathrm{Y})$ melalui Kepuasan Pelanggan $(\mathrm{X} 3)=$ $\rho \times 3 \times 1 \times \rho y \times 3=(0,562) \times(0,500)=0,281(28,1 \%)$. Dengan demikian pengaruh totalnya $=(\rho y \times 1)^{2}+I E=$ $0,0510+0,281=\mathbf{0 , 3 3 2}(\mathbf{3 3}, \mathbf{2 \%})$.

2. Pengaruh tidak langsung, Kepercayaan Merek (X2) ke Loyalitas Pelanggan (Y) melalui Kepuasan Pelanggan $(\mathrm{X} 3)=\rho \times 3 \times 2 \times \rho y \times 3=(\mathbf{0 , 2 7 4}) \times(\mathbf{0 , 5 0 0})=\mathbf{0 , 1 3 7}(\mathbf{1 3 . 7 \%})$. Dengan demikian pengaruh totalnya $=(\boldsymbol{\rho} \mathbf{y} \mathbf{2})^{2}+\mathrm{IE}$ $=0,04+0.137=\mathbf{0}, \mathbf{1 7 7}(\mathbf{1 7 , 7 \%})$.

\subsection{Pembahasan}

Berdasarkan hasil pengolahan data, citra merk berpengaruh terhadap kepuasan pelanggan. Hal ini menunjukkan bahwa apabila perusahaan senantiasa membentuk citra modern, melayanis semua segemen, concern pada konsumen dan popular. Dampaknya adalah, konsumen akan merasa puas karena menggunakan merek produk yang dikenal luas oleh masyarakat. Hasil ini sesuai dengan teori Tjiptono (2005 : 20) yang menyatakan bahwa sebuah merek bisa dikatakan sukses (successful brand) apabila pembeli atau pemakainya mempersiapkan adanya nilai tambah relevan, unik, dan berkesinambungan yang memenuhi kebutuhannya secara paling memuaskan. Merek sukses sebagai nama, simbol, desain, atau kombinasi di antaranya mengidentifikasikan produk organisasi tertentu dengan keunggulan diferensial berkesinambungan. Kriteria utama di sini adalah (1)keunggulan diferensiasial yakni Konsumen memiliki alasan kuat untuk lebih menyukai merek bersangkutan dibanding merek-merek pesaing; dan (2)langgeng atau berhubungan (sustaitnable), artinya keunggulan yang tidak mudah ditiru para pesaing, di mana perusahaan menciptakan hambatan masuk, misalnya dengan jalan mengembangkan reputasi atau citra unik dan kokoh dalam hal kualitas, layanan, atau reliabilitas. Merek sukses selalu merupakan pemimpin dalam segmen pasar yang di layaninya. Brand image dapat terbentuk sesuai atau mendekati.

Berdasarkan hasil pengolahan data, Kepercayaan merk berpengaruh terhadap kepuasan pelanggan. Hasil ini menunjukkan bahwa pelanggan merasa bahwa Toshiba sudah sesuai dengan kebutuhan pelanggan. Kepercayaan pelanggan pada merek memberikan kontribusi pada intensi pelanggan untuk membeli kembali merek yang sama di masa akan datang, dan intensi mereka untuk merekomendasikan merek tersebut pada orang lain. Oleh karena itu, pemasar perlu membangun kepercayaan pelanggan pada merek yang mereka tawarkan. Untuk membangun kepercayaan pada merek, pemasar perlu memahami dan mengembangkan karakteristik-karakteristik yang mempengaruhi kepercayaan pelanggan pada merek, yaitu karakteristik merek, karakteristik perusahaan dan karakteristik hubungan pelanggan-merek. Hal ini sesuai dengan teori Lau dan Lee (1999: 44 ), terdapat tiga faktor yang mempengaruhi kepercayaan terhadap merek. Ketiga factor ini berhubungan dengan tiga entitas yang tercakup dalam hubungan antara merek dan Pelanggan. Adapun ketiga faktor tersebut adalah merek itu sendiri, perusahaan pembuat merek, dan Pelanggan. Selanjutnya Lau dan Lee memproposisikan bahwa kepercayaan terhadap merek akan menimbulkan kepuasan.

Berdasarkan hasil pengujian diatas, diperoleh hasil citra merek berpengaruh terhadap Loyalitas Pelanggan. Hal ini menunjukkan bahwa semakin baik citra merek akan meningkatkan Loyalitas Pelanggan. Hasil ini sesuai dengan teori Schiffman dan Kanuk (2009), loyalitas merek adalah preferensi konsumen secara konsisten untuk melakukan pembelian pada merek yang sama pada produk yang spesifik atau kategori pelayanan tertentu. Hubungan antara citra merek dengan loyalitas merek terletak pada keinginan-keinginan dan pilihan konsumen (preference) atas suatu merek adalah merupakan sikap konsumen. Konsumen akan menunjukkan Loyalitas Pelanggan ketika ia tidak hanya melakukan pembelian berulang tapi ia juga benar-benar menyukai dan memilih merek tersebut. 
Berdasarkan hasil pengolahan data, kepuasan pelanggan berpengaruh terhadap Loyalitas Pelanggan,. Hal ini berarti bahwa jika kepuasan pelanggan tinggi, maka loyalitas pelanggan juga tinggi. Hasil ini menunjukkan bahwa upaya perusahaan untuk memberikan yang terbaik bagi pelanggannya agar apa yang diharapkan oleh mereka sesuai dengan kenyataan sehingga mereka puas dan akan membentuk pengalaman konsumsi yang positif. Hal ini mendukung sepenuhnya Samuel (2007 : 77) yang berpendapat bahwa jika pelanggan puas akan suatu merek tertentu dan sering membeli produk tersebut maka dapat dikatakan tingkat Loyalitas Pelanggan itu tinggi, sebaliknya jika Pelanggan tidak terlalu puas akan suatu merek tertentu dan cenderung untuk membeli produk dengan merek yang berbeda-beda maka tingkat Loyalitas Pelanggan rendah. Kepuasan Pelanggan perlu dipelihara dan ditingkatkan agar dapat menciptakan dan mempertahankan Loyalitas terhadap merek.

\section{Penutup}

\subsection{Kesimpulan}

Berdasarkan hasil pengujian dengan menggunakan analisis untuk menguji pengaruh citra merek, kepercayaan pada merk dan kepuasan terhadap loyalitas merek, maka dapat diambil kesimpulan sebagai berikut :

1. Citra Merek berpengaruh positif dan signifikan terhadap Kepuasan Pelanggan

2. Kepercayaan Merek berpengaruh positif dan signifikan terhadap Kepuasan Pelanggan

3. Citra Merek berpengaruh positif dan signifikan terhadap Loyalitas Pelanggan

4. Kepercayaan Merek berpengaruh positif dan signifikan terhadap Loyalitas Pelanggan

5. Kepuasan Pelanggan berpengaruh positif dan signifikan terhadap Loyalitas Pelanggan

\subsection{Saran}

Sehubungan dengan permasalahan dan hasil analisa data yang telah disajikan dimuka, maka dapat dikemukakan beberapa saran yang bermanfaat bagi perusahaan, adapun saran-saran tersebut sebagai berikut :

1. Pada penelitian ini variable kepercayaan terhadap loyalitas memiliki hubungan yang paling rendah, diharapkan perusahaan lebih menunjukkan perhatiannya kepada konsumen dengan lebih memperbanyak Toshiba Center di berbagai wilayah.

2. Diharapkan pihak perusahaan lebih meningkatkan citra merek, dengan menambah atribut atau ciri merek yang menjadi keunggulan produk Toshiba, karena karakteristik merek memainkan peran yang vital dalam menentukan apakah pelanggan memutuskan untuk percaya pada suatu merek.

3. Mengingat loyalitas mereknya belum berada pada tingkatan committed buyer, maka perusahaan perlu selalu memperbaiki dan meningkatkan kualitas produknya secara keseluruhan agar konsumen semakin percaya dan mau menyarankan dan mempromosikan kepada orang lain. Selain itu perusahaan juga perlu menjaga hubungan dan kedekatan yang saling menguntungkan dengan memberikan pelayanan ekstra atau gratis dan hadiah kepada konsumen untuk meningkatkan loyalitasnya.

\section{Daftar Pustaka}

Aaker, A. David. 2008. Manajemen Ekuitas Merek. Alih bahasa oleh Aris Ananda. Jakarta: Mitra Utama Arikunto, S. 2010. Prosedur penelitian : Suatu Pendekatan Praktik. (Edisi Revisi). Jakarta : Rineka Cipta

Bastian, D. Alexander. 2014. Analisa Pengaruh Citra Merek (Brand Image) dan Kepercayaan Merek (Brand Trust) Terhadap Loyalitas Merek (Brand Loyalty) ADES PT. Ades Alfindo Putra Setia. Jurnal Manajemen Pemasaran Petra, Vol. 2, No. 1, hal. 1-9

Kotler, Philip. 2002. Manajemen Pemasaran, Analisa perencanaan, Implementasi dan control, Edisi Kesembilan, Jilid 1 dan jilid 2, Jakarta

Kotler, Philip. 2005. Manajemen Pemasaran I-Edisi Kesebelas. Jakarta

Kotler, Philip dan Kevin Lane Keller, 2012. Marketing Management Edisi 14, Global Edition.Pearson Prentice Hall. Oliver, Sandra. 2007. Strategi Public Relations. Jakarta : Esensi.

Tjiptono, Fandy. 2011. Strategi Pemasaran. Yogyakarta : Liberty : 42.

Kotler, Philip. 2006. Marketing Management 12. Pearson International Edition.

Musanto, Tri, 2010, Faktor-Faktor Kepuasan Pelanggan dan Loyalitas Pelanggan: Studi Kasus pada CV. Sarana Media Advertising Surabaya

Ramadhana, 2010, Pengaruh Citra Merek Terhadap Kepuasan Dan Loyalitas Pelanggan (Studi Pada Pelanggan Operator Telekomunikasi Indosat di Kota Malang)

Rangkuti, Freddy. 2004. The Power of Brand. Jakarta: PT. Gramedia Pustaka Utama. 